\title{
Adipose-Derived Stromal/Stem Cells
}

\author{
Patrick C. Baer
}

Division of Nephrology, Department of Internal Medicine III, University Hospital, Goethe-University, 60596 Frankfurt am Main, Germany; patrick.baer@kgu.de or p.baer@em.uni-frankfurt.de; Tel.: +49-69-6301-5554; Fax: +49-69-6301-4749

Received: 21 August 2020; Accepted: 25 August 2020; Published: 30 August 2020

check for updates

Adipose tissue is a rich, ubiquitous, and easily accessible source for multipotent mesenchymal stromal/stem cells (MSCs), so-called adipose-derived stromal/stem cells (ASCs). Primary isolated ASCs are a heterogeneous preparation consisting of several subpopulations of stromal/stem and precursor cells. Donor-specific differences in ASC isolations and the lack of culture standardization hinder the comparison of results from different studies. Nevertheless, ASCs are already used in different in vivo models and clinical trials to investigate their ability to improve tissue and organ regeneration. Many questions concerning their counterparts and biology in situ, their differentiation potential in vitro and in vivo, and also the mechanisms of regeneration (paracrine effects including regeneration promoting factors and extracellular vesicles, differentiation, immunomodulation) are not completely understood or remain unsolved. For this reason, this special edition aims to expand current knowledge about the extremely diverse potential of ASCs.

This Special Issue covers research articles investigating various adipose tissues as a source for ASC isolation [1-3], specific cultures methods to enhance proliferation or viability [4-7], and the differentiation capacity [8-12]. Furthermore, other studies highlight aspects of various diseases [13,14], the immunosuppressive potential of ASCs and their derivates [15] or the in vivo tracking of transplanted ASCs [16].

Ritter and co-workers analyzed the functional similarities and differences of ASCs isolated from different adipose depots [3]. The authors described that ASCs isolated from subcutaneous and visceral fat share multiple cellular features, but significantly differ in their functions. The functional diversity of ASCs depends on their origin, cellular context, and surrounding microenvironment within adipose tissues. Stojanović and co-workers characterized the molecular signature and the differentiation capacity of ASCs isolated from lipoma [2]. A study by our group from the nephrological research laboratory summarized the isolation and culture of ASCs from perirenal adipose tissue, characterized the cultured cells, and demonstrated their immunomodulatory potential and their high permissiveness for human cytomegalovirus [1].

Platelet lysate has been shown to be an effective replacement for serum in the culture, expansion, and differentiation of ASCs [4,7]. Metformin has been shown as a preconditioning agent that stimulates proliferative activity and viability of ASCs [6]. The addition of metformin improved metabolism and viability, correlated with higher mitochondrial membrane potential, and reduced apoptosis. As a possible alternative to standard cell culture, Ryu and co-workers reviewed spheroid culture systems that could provide a physicochemical environment similar to that in vivo by facilitating cell-cell and cell-matrix interaction, thereby overcoming the limitations of traditional monolayer cell culture [5].

The findings of $\mathrm{Ng}$ and co-workers suggest that the epigenetic state of MSCs is associated with the biased differentiation plasticity towards its tissue of origin, proposing a mechanism related to the retention of epigenetic memory [11]. This result could improve the selection of optimal tissue sources for MSCs for therapeutic applications. Others studied various effects of differentiation events induced by differentiation-inducing agents. Using valproic acid, the induced neural differentiation of ASCs was demonstrated by the upregulation of characteristic neuro-specific factors [8]. Zöller and 
co-workers showed that collagen I was able to modulate lipogenesis and adiponectin expression, and hypothesized that this could contribute to age-related metabolic disorders [10]. Klemenz and co-workers determined volatile organic compounds during adipogenic differentiation of ASCs in order to avoid cell destruction during monitoring of cell status [9]. Their data indicated that measuring these compounds could be a useful, non-invasive tool for the metabolic monitoring of cells in vitro. Di Somma and co-workers tested the ability of Histogel, a natural mixture of glycosaminoglycans, to sustain the differentiation of ASCs into brown-like cells and brown adipose tissue [12]. A study by Plava and co-workers identified that ASCs are permanently altered in the presence of tumor breast tissue and have the potential to increase tumor cell invasive ability through the activation of epithelial-to-mesenchymal transition in tumor cells [13]. Another study characterized ASCs isolated from patients with rheumatoid arthritis and described their altered phenotype and secretory activity compared to ASCs from healthy donors [14].

In recent years, several in vitro preconditioning (also called pretreatment or licensing) strategies have been investigated to enhance the regenerative and immunomodulatory potential of ASCs. Serejo and co-workers investigated how a preconditioning regime with interferon- $\gamma$ affects the immunomodulatory functions of ASCs and examined their secretome and released extracellular vesicles [15]. Preconditioned ASCs showed a higher immunosuppressive potential compared to unlicensed ASCs. Another study by our group from the nephrological research laboratory shows in vivo tracking of luciferase-transgenic ASCs after transplantation in a model of inflammatory lung disease [16]. In vivo imaging demonstrated a significantly longer retention time of transplanted ASCs in the injured lung parenchyma compared to healthy wild type mice, which could indicate increased regeneration of the damaged tissue.

Funding: The author received no funding for this editorial.

Conflicts of Interest: The author declares no conflict of interest.

\section{References}

1. Baer, P.C.; Koch, B.; Hickmann, E.; Schubert, R.; Cinatl, J.; Hauser, I.A.; Geiger, H. Isolation, Characterization, Differentiation and Immunomodulatory Capacity of Mesenchymal Stromal/Stem Cells from Human Perirenal Adipose Tissue. Cells 2019, 8, 1346. [CrossRef] [PubMed]

2. Stojanović, S.; Najman, S.; Korać, A. Stem Cells Derived from Lipoma and Adipose Tissue-Similar Mesenchymal Phenotype but Different Differentiation Capacity Governed by Distinct Molecular Signature. Cells 2018, 7, 260. [CrossRef] [PubMed]

3. Ritter, A.; Friemel, A.; Roth, S.; Kreis, N.-N.; Hoock, S.C.; Safdar, B.K.; Fischer, K.; Möllmann, C.; Solbach, C.; Louwen, F; et al. Subcutaneous and Visceral Adipose-Derived Mesenchymal Stem Cells: Commonality and Diversity. Cells 2019, 8, 1288. [CrossRef] [PubMed]

4. Cowper, M.; Frazier, T.; Wu, X.; Curley, L.; Ma, M.H.; Mohuiddin, O.A.; Dietrich, M.; McCarthy, M.; Bukowska, J.; Gimble, J.M. Human Platelet Lysate as a Functional Substitute for Fetal Bovine Serum in the Culture of Human Adipose Derived Stromal/Stem Cells. Cells 2019, 8, 724. [CrossRef] [PubMed]

5. Ryu, N.-E.; Lee, S.-H.; Park, H. Spheroid Culture System Methods and Applications for Mesenchymal Stem Cells. Cells 2019, 8, 1620. [CrossRef] [PubMed]

6. Smieszek, A.; Kornicka, K.; Szłapka-Kosarzewska, J.; Androvic, P.; Valihrach, L.; Langerova, L.; Rohlova, E.; Kubista, M.; Marycz, K. Metformin Increases Proliferative Activity and Viability of Multipotent Stromal Stem Cells Isolated from Adipose Tissue Derived from Horses with Equine Metabolic Syndrome. Cells 2019, 8, 80. [CrossRef] [PubMed]

7. Kakudo, N.; Morimoto, N.; Ma, Y.; Kusumoto, K. Differences between the Proliferative Effects of Human Platelet Lysate and Fetal Bovine Serum on Human Adipose-Derived Stem Cells. Cells 2019, 8, 1218. [CrossRef] [PubMed]

8. Santos, J.; Hubert, T.; Milthorpe, B.K. Valproic Acid Promotes Early Neural Differentiation in Adult Mesenchymal Stem Cells Through Protein Signalling Pathways. Cells 2020, 9, 619. [CrossRef] [PubMed] 
9. Klemenz, A.-C.; Meyer, J.; Ekat, K.; Bartels, J.; Traxler, S.; Schubert, J.K.; Kamp, G.; Miekisch, W.; Peters, K. Differences in the Emission of Volatile Organic Compounds (VOCs) between Non-Differentiating and Adipogenically Differentiating Mesenchymal Stromal/Stem Cells from Human Adipose Tissue. Cells 2019, 8, 697. [CrossRef] [PubMed]

10. Zöller, N.; Schreiner, S.; Petry, L.; Hoffmann, S.; Steinhorst, K.; Kleemann, J.; Jäger, M.; Kaufmann, R.; Meissner, M.; Kippenberger, S. Collagen I Promotes Adipocytogenesis in Adipose-Derived Stem Cells In Vitro. Cells 2019, 8, 302. [CrossRef] [PubMed]

11. Ng, T.T.; Mak, K.H.-M.; Popp, C.; Ng, R.K. Murine Mesenchymal Stromal Cells Retain Biased Differentiation Plasticity Towards Their Tissue of Origin. Cells 2020, 9, 756. [CrossRef] [PubMed]

12. Di Somma, M.; Schaafsma, W.; Grillo, E.; Vliora, M.; Dakou, E.; Corsini, M.; Ravelli, C.; Ronca, R.; Sakellariou, P.; Vanparijs, J.; et al. Natural Histogel-Based Bio-Scaffolds for Sustaining Angiogenesis in Beige Adipose Tissue. Cells 2019, 8, 1457. [CrossRef] [PubMed]

13. Plava, J.; Cihova, M.; Burikova, M.; Bohac, M.; Adamkov, M.; Drahosova, S.; Rusnakova, D.; Pindak, D.; Karaba, M.; Simo, J.; et al. Permanent Pro-Tumorigenic Shift in Adipose Tissue-Derived Mesenchymal Stromal Cells Induced by Breast Malignancy. Cells 2020, 9, 480. [CrossRef] [PubMed]

14. Kuca-Warnawin, E.; Skalska, U.; Janicka, I.; Musiałowicz, U.; Bonek, K.; Głuszko, P.; Szczęsny, P.; Olesińska, M.; Kontny, E. The Phenotype and Secretory Activity of Adipose-Derived Mesenchymal Stem Cells (ASCs) of Patients with Rheumatic Diseases. Cells 2019, 8, 1659. [CrossRef] [PubMed]

15. Serejo, T.R.T.; Silva-Carvalho, A.É.; Braga, L.D.d.C.F.; Neves, F.d.A.R.; Pereira, R.W.; Carvalho, J.L.D.; Saldanha-Araujo, F. Assessment of the Immunosuppressive Potential of INF- $\gamma$ Licensed Adipose Mesenchymal Stem Cells, Their Secretome and Extracellular Vesicles. Cells 2019, 8, 22. [CrossRef] [PubMed]

16. Baer, P.C.; Sann, J.; Duecker, R.P.; Ullrich, E.; Geiger, H.; Bader, P.; Zielen, S.; Schubert, R. Tracking of Infused Mesenchymal Stem Cells in Injured Pulmonary Tissue in Atm-Deficient Mice. Cells 2020, 9, 1444. [CrossRef]

(C) 2020 by the author. Licensee MDPI, Basel, Switzerland. This article is an open access article distributed under the terms and conditions of the Creative Commons Attribution (CC BY) license (http://creativecommons.org/licenses/by/4.0/). 